\title{
Improvement of Business Performance Through Strengthening Islamic Financial Literacy and Entrepreneurial Orientation: Study on Women Enterprises in Jambi City
}

\author{
Rike Setiawati ${ }^{1, *}$ Besse Wediawati $^{2}$, Heriberta $^{3}$ \\ ${ }^{1,2,3}$ Lecturer in Economics \& Business Faculty Jambi University, Jambi-Indonesia \\ *Corresponding Author: E-mail: rike_setiawati@unja.ac.id
}

\begin{abstract}
Islamic financial literacy and entrepreneurial orientation are important factors needed by micro and small enterprises (MSEs) to run a business and achieve its performance. This study will examine the effect of Islamic financial literacy and entrepreneurial orientation on business performance. The research sample was Muslim women entrepreneurs in Jambi city, as many as 55 micros, small and medium enterprises, which were collected through questionnaires and interviews with the purposive sampling method. Quantitative data analysis uses structural equation models with the Partial Least Square (PLS) approach. The results showed that for the questionnaire with objective questions, the majority of women entrepreneurs were able to answer correctly, but the question about the financing simulation with the Murabaha contract, more answered they did not know. Furthermore, the results of quantitative data analysis show that Islamic financial literacy and entrepreneurial orientation have a significant positive effect on the performance of women entrepreneurial businesses
\end{abstract}

Keywords: Islamic Financial Literacy, Entrepreneurial Orientation, Business Performance, Muslim Women Entrepreneurs.

\section{INTRODUCTION}

The issue of gender equality and access to the world of business which is increasingly widespread in the current era has opened up great opportunities for women to be able to pursue businesses that match their interests and talents so that they can prove their success. The success of an entrepreneurial woman should be considered more because of the role of a woman by nature as a wife or housewife, while on the other hand, she can manage a business despite the many obstacles that must be faced. Women entrepreneurs are still a minority in the business world and are still dominated by men, as stated by [1]. To reduce gender disparities in the labor market and promote women's empowerment is through entrepreneurship development [2]. Although the World Bank (2011) states that in almost all countries, women are more likely to be involved in low productivity activities than men. Therefore, as an important human resource for the nation and through encouragement for entrepreneurial women, the state must try to use it as a mediator for economic growth and development [3].

Business performance is assessed by how managers can make the right decisions for the continuity of their business by utilizing existing resources for business operational matters such as finance, marketing, technology, and other issues, by adhering to effective and efficient principles so that it will create additional cash inflow in the future. come. To make the right financial decisions in finding sources of spending, allocating and deciding on choosing instruments, or accessing financial markets requires knowledge and understanding related to financial literacy. This is in line with the statement that to make financial decisions and achieve individual welfare, financial literacy is needed, which is a combination of awareness, attitude, and behavior. [4]. Likewise, it is stated that the activities of saving, borrowing, investing, and managing finances will be influenced by their success by financial literacy [5]. Financial skills also emphasize the ability to properly 
understand and apply the basic concepts of economics and finance.

Numerous studies have interpreted the importance of financial literacy in both the business sector to make the right decision or as individuals. To improve business performance, financial literacy has a significant role, therefore entrepreneurs need to improve their financial literacy. The results of the study found that the dimensions of financial literacy have a significant relationship with entrepreneurial business performance, which proves that financial literacy plays an important role in improving business performance [6]. Financial literacy can also increase participation in financial markets and access to a wider range of funding sources [7]. Research on financial literacy towards individuals to improve the welfare of the financial literacy community has also been widely studied and resulted in findings that the lack of individual financial literacy has a negative effect on the economy [8], people's lack of understanding of the financial system [9], and[10], and show that financial literacy has an effect on welfare accumulation and portfolio choice [7].

On the other hand, entrepreneurial orientation is also considered and recognized as a variable that has a relationship with business success. According to research results in a positive relationship between entrepreneurial orientation and business performance in dynamic environmental conditions [11]. Other studies have found a U-shaped inverse relationship between entrepreneurial orientation and performance in new ventures, but there is a positive relationship with established businesses [12]. Another finding of local Tanzanian construction companies states that the dimensions of innovation and risk-taking have a significant positive effect on profitability growth, while the proactive dimension has a significant negative effect [13].

Other similar findings which state that entrepreneurial orientation has a positive effect on business performance include [14]; [15]; and [16].

In Indonesia, micro-business actors are currently dominated by women and on average they are engaged in culinary, education, garment, fashion, handicraft, cosmetics, spa, and other businesses. Data from the Indonesian women entrepreneurs association (IWAPI) states that IWAPI has more than 30,000 women entrepreneurs consisting of $85 \%$ small and micro enterprises, $13 \%$ medium enterprises, and $2 \%$ large scale businesses http://iwapi.id/dpd-iwapi-provinsi-jambi/

The researches that have been done link financial literacy and entrepreneurial orientation to business performance, however studies related to Islamic financial literacy are still relatively difficult to find. The need for Islamic financial literacy research is not only due to internal factors in the Muslim entrepreneurial community, namely due to its obligation to comply with
Islamic rules, but also due to external factors, namely the availability (supply) of financial instruments that are so complex and make the Muslim community aware of it by making financial decisions based on literacy. Islamic finance.

Based on the phenomena and problems described, this research is important to do to find the right model of how to improve business performance through strengthening Islamic financial literacy and entrepreneurial orientation of Muslim women entrepreneurs in the city of Jambi. This research was conducted for the first time on Muslim women entrepreneurs to produce a study of the level of Islamic financial literacy based on the dimensions of knowledge, attitudes, and behavior, then what is the role of entrepreneurial orientation in improving business performance for women entrepreneurs.

\section{LITERATURE REVIEW}

\subsection{Islamic Financial Literacy and Business Performance}

Business performance is a measure of the success of managing a business concerning the achievement of previously planned goals which are influenced by many factors [17]. Characterize performance as a company's ability to create results and actions and underline the use of performance that can be used as an index of business health during a special period. Entrepreneurs who are better and more financially literate are more likely to take advantage of financial services such as bank accounts [18]. Furthermore, research conducted in Bosnia and Herzegovina concluded that although training programs did not affect business continuity, they did significantly improve business practices, investment and loan requirements and women-run businesses showed some improvement in business performance and sales [19]. The findings of [20] in their research on small and micro enterprises in Nairobi, Kenya that as many as $50 \%$ have poor performance and 62 percent of them are women businesses. SMEs face challenges of competition among themselves and from large companies, lack of access to credit, cheap imports, insecurity, and debt collection. Research conducted in Kenya found that debt management literacy is still not comprehensive, especially concerning the effect of inflation and interest rates on loans, as well as his business bookkeeping [21]. These findings are also reinforced by the results of other studies that bookkeeping literacy, budgeting literacy, and financial inclusion have a positive and significant effect on the financial performance of SMEs [22]. Other findings also show that financial literacy about loans and budgets has a significant effect on the performance of SMEs [23]. Other research shows that the financial literacy of business owners is still low and most microcompany owners are not involved in financial planning, 
budgeting, and formal financial control and only keep a few account books [24].

Meanwhile, Islamic financial literacy is still a new topic in financial literacy research, and the concept is still relatively limited. Research that discusses Islamic financial literacy does not define it explicitly and refers to the definition of conventional financial literacy that is adjusted to the system and obligations that must be met in Islamic finance. Islamic financial literacy is divided into three dimensions, namely knowledge, attitudes, and behavior of Islamic finance, each of which has indicators [25]. In a broader sense, Islamic financial literacy consists of basic wealth or financial management (income, consumption, and savings), financial planning (takaful, pension schemes, and sharia-based investment), zakat, inheritance law (faraid) and wasiyyah, alms (waqf). and alms) [26]. Two other researchers use the term halal literacy which focuses on a person's ability to distinguish between halal and haram products and services based on Sharia [27]; [28].

The Islamic financial literacy variable in this study refers to research [25], namely a person's ability from the aspects of knowledge, attitudes, and behavior in managing finances, namely selecting sources and uses of funds and making the right decisions based on financial principles. sharia to achieve a prosperous muamalah life. The dimensions used are knowledge of Islamic finance, Islamic financial attitudes, and behavior of Islamic finance with indicators based on Islamic financial principles, namely not containing maysir (gambling/speculation), gharar (unclear/vague), usury, risk sharing, enforcing money. as a means of transaction and precautionary motive, maintaining sanctity in contracts or transaction agreements and conducting economic activities based on sharia. All these findings indicate the importance of financial literacy for individuals and the business world or as entrepreneurs in improving performance.

\subsection{Entrepreneurial Orientation and Business Performance}

Entrepreneurial orientation is defined as the process of making corporate strategies and styles in entrepreneurial activities [29]. EO is also interpreted as a way of doing entrepreneurship with the methods, practices, and decision-making styles used to act in an entrepreneurial manner [30]. Further entrepreneurial orientation stated reflects the extent to which companies tend to innovate, take risks, and act proactively [31].

As the research finding [12] that the relationship between entrepreneurial orientation and performance is inverted U-shaped in new ventures but positive in established companies. In its implementation, it is suggested that companies adjust entrepreneurial orientation with supporting resources and organizational structure so that increases and company performance becomes better. One dimension of entrepreneurial orientation, namely risk-taking and informal networks within its institutional framework, has a significant positive effect on SME performance [15]. Furthermore, it was also found that leverage has a significant moderating role through interaction with the entrepreneurial orientation dimension[14].

Another finding states that entrepreneurial orientation has a positive and significant effect on the performance of MSMEs in Abia State, Nigeria [32]. Furthermore, the results of research using the entrepreneurial orientation variable dimensions Lumpkin and Dess (1996)[29] state that there are four dimensions, namely innovativeness, proactivity, risk-taking and aggressiveness affect performance while no correlation is found on autonomy in the context of technology-based SMEs in Malaysia [33]. A positive relationship between entrepreneurial orientation and business performance in dynamic environmental conditions was also found from research [11] dan [34].

\section{METHOD}

This quantitative study uses primary data collected through a structured questionnaire with a Likert scale to 55 samples of entrepreneurs in Jambi City. The sampling method used was purposive sampling technique where the sample frame was women entrepreneurs who are members of the IWAPI organization and traders in the Gang Siku traditional market who have the criteria; (1) has been established for more than 3 years, (2) has $\geq 2$ employees. The variables of business performance and level of Islamic financial literacy and entrepreneurial orientation are explained based on demographic and socio-economic characteristics (the type of business, length of business, age, level of education, and income). Furthermore, the variable relationship model is found through regression analysis using the help of the Partial Least Square Structural Equation Modeling tool.

\subsection{Operationally the variables used are defined as follows:}

\subsubsection{Business Performance (KU)}

is understood as the ability of a business to generate profits to increase business, which is proxied from financial and non-financial aspects in the form of sales volume, profit and number of customers, product development, and additional business capital. The measure of this business performance mostly uses interview data in the form of respondents' perceptions regarding the business they are engaged in, because there is no adequate financial report from the business actor. 


\subsubsection{Islamic Financial Literacy}

is defined as a person's ability from the aspects of knowledge, attitudes, and behavior in managing finances, namely in selecting sources and uses of funds and making the right decisions based on sharia-based financial principles to achieve a prosperous muamalah life [26]. The dimensions are:

a. Islamic Financial Knowledge, with measurement indicators in the form of knowing the concepts and laws in Islamic finance, knowing Islamic financial products, knowing Islamic financial contracts, and knowing the implementation mechanisms of Islamic finance

b. Islamic Financial Attitudes, with measurement indicators in the form of awareness in finding sources of financing and spending money in a halal manner, awareness of allocating useful funds, having the principle of frugality, awareness of the principle of mutual trust, awareness of the use of halal and safe products and services, and Awareness of sharia rules

c. Islamic Financial Behavior, with measurement indicators in the form of planning and having good financial goals, choosing sources of income and how to get it that is halal, and choosing the right allocation of funds.

d. Entrepreneurship orientation is interpreted as a description of the efforts that have been made by business actors from the dimensions of innovation, being proactive and taking risks, which refers to the research of Frishammar and Horte (2007)[31], namely:

1. Innovation (OK_1) with indicators of measuring efforts to find new ideas, supporting the emergence of new product ideas, supporting creativity for the emergence of new products, and trying out new business processes.

2. Proactive (OK_2) with an indicator measuring the ability to look for positive opportunities for his business when market conditions change, the first person to take action to secure the market, takes anticipatory action against future demand and the effort he does is usually a pioneer in introducing new products

3. Risk-taking (OK_3) with indicators measuring efforts to bear the risk of unsold products, risking the company being closed, risking financial loss, preferring to run a safe business, or having small risks and preferring to implement plans that are sure to be successful.

\section{RESULTS}

\subsection{Characteristics of Respondents}

The subjects of this study were 55 Muslim women entrepreneurs in Jambi City who were classified as micro and small enterprises (MSEs). The majority of respondents (45\%) are involved in the culinary business, with a monthly income of around five million rupiahs, while others such as trading (35\%) and services $(20 \%)$ whose majority income is also around five million rupiahs. Judging from the length of business, the trading business has been involved for 5.1 years, while the culinary and service business is not too different, namely for 4.8 years and 4.5 years, respectively. When viewed from the age of entrepreneurship, the majority of women entrepreneurs aged 40 - 59 years have been in business for the longest, namely 5.2 years. Judging from the level of education both in culinary, trade, and service businesses, the majority of women entrepreneurs have high school education and a small proportion have S1 and D3 degrees. The complete descriptive data is shown in Figure 1- 4 below:

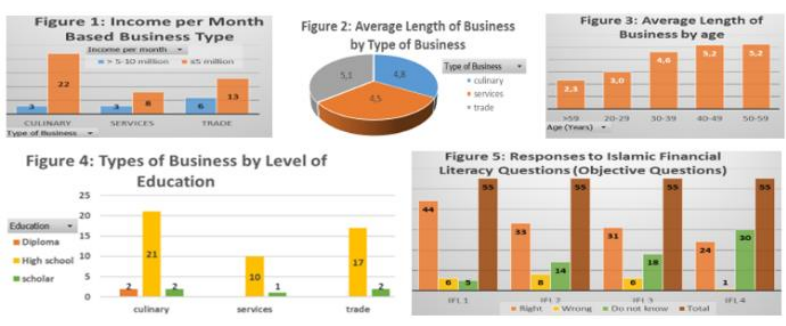

\subsection{Islamic Financial Literacy for Muslim Women Entrepreneurs}

The Islamic financial literacy variable in this study uses two types of questions, namely objective questions and statements that are subjective. From the objective questions as the basic knowledge of female entrepreneurial financial literacy, four questions are given about simulations related to Sharia products/contracts. The results show that the majority of women entrepreneurs can answer correctly, except for the question of the murabahah contract financing simulation, more people who answer do not know. This indicates that the level of knowledge of Muslim women entrepreneurs towards sharia products and contracts is relatively high as shown in Figure 5. When viewed from the characteristics of age, type of business, length of business, income, and income, the average Islamic financial literacy of these women entrepreneurs is also not many different scores.

Subjective Islamic financial knowledge has five indicators/statements, namely related to knowledge of concepts and laws, financial planning, products, and contracts, as well as the implementation mechanism of Islamic finance with answer options ranging from highest 
to lowest, namely Very Know, Know, Doubt, Don't Know and Very Do not know with a score of 5 to 1 . The majority of women entrepreneurs> $50 \%$ answered "Doubt" with a score of 3 on indicators 1-3,4, and 5, and the answer "Very Know" (51\%) on indicator 2. So that this dimension produces an average score of 3.46. Thus it can be said that the descriptive findings from the knowledge side both subjectively and objectively, Muslim women entrepreneurs have good knowledge of Islamic finance and respond with a fairly good attitude as well.

The second dimension is the attitude of Islamic finance which has five indicators, namely awareness and confidence in finding sources of halal financing, having the principle of frugality, awareness, and belief in the principle of mutual trust, awareness and belief in the use of halal products and services, and awareness and belief in the rules. sharia. In this dimension the majority of female Muslim entrepreneurs> 50\%, give an answer "Agree" with a score of 4 on indicators 1, 3, 4, and 5, then on indicator 2 the majority (54.55\%), answer "Strongly Agree". So that this dimension produces an average score of 4.08 .

The third dimension is the behavior of Islamic finance which has three indicators, namely planning and having good financial goals, choosing sources of income and lawful methods, choosing the right allocation of funds, paying obligations on time, and actively saving/investing. The majority of Muslim women entrepreneurs (> 65\%) answered "often" on indicators 2 to 5 of the statement, while in indicator 1 the majority of entrepreneurs answered "sometimes" $(60 \%)$, so this dimension produces an average score of 4,02 . Overall, the score compared to the maximum score in the variable level of Islamic financial literacy is $3.85(82 \%)$ which is in the Literate range.

\section{DISCUSSION}

The independent variable in this study consisted of Islamic financial literacy and entrepreneurial orientation, while the dependent variable was business performance. The variable construct of Islamic financial literacy (LKI) has three dimensions, namely Islamic financial knowledge (LKI_1), Islamic financial attitudes (LKI_2), and Islamic financial behavior (LKI_3), each of which has five indicators/statements. Meanwhile, the entrepreneurial orientation $(\mathrm{OK})$ variable construct has three dimensions, namely innovation, proactive, and risktaking, each of which has three indicators/statements. Meanwhile, the business performance variable has nine indicators/statements.

Based on the evaluation of the measurement model (outer model), it shows that the model built in the study has the required level of validity and reliability. Tests are carried out on both the dimensional forming indicators and the latent construct-forming dimensions, using Confirmatory Factor Analysis (CFA). Based on the evaluation of the measurement model (outer model), it shows that the model built in the study has the required level of validity and reliability. Tests are carried out on both the dimensional forming indicators and the latent construct-forming dimensions, using Confirmatory Factor Analysis (CFA). The reflective indicator model of Islamic financial literacy (IFI), entrepreneurial orientation $(\mathrm{OK})$ has a multidimensional construct, meaning that this variable has a dimension as a first order, and this dimension requires indicators in its measurement as a second-order, while the business performance variable (KU) has a unidimensional construct. where the latent construct is reflected directly by the indicators as physical order. The outer reflective indicator model was evaluated through convergent and discriminant validity of the latent construct-forming indicators and composite reliability and Cronbach alpha for the indicator block (Chin 1998). Statistical analysis using the Smart PLS 3.00 program. All indicators/statement items used to measure the construct of Islamic financial literacy variables from the three dimensions of knowledge, attitudes, and behavior are declared valid. Likewise, the construct statement items for the entrepreneurial orientation variable from three dimensions, namely innovation, proactivity, and risk-taking, were all declared valid. The statement items for the construct of business performance variables from nine statements, 8 items were declared valid, but 1 item namely KU_6 was declared invalid. From these results, invalid statement items were removed from the model, then models with valid indicators/statements as presented in Figures 6 and 7 below:

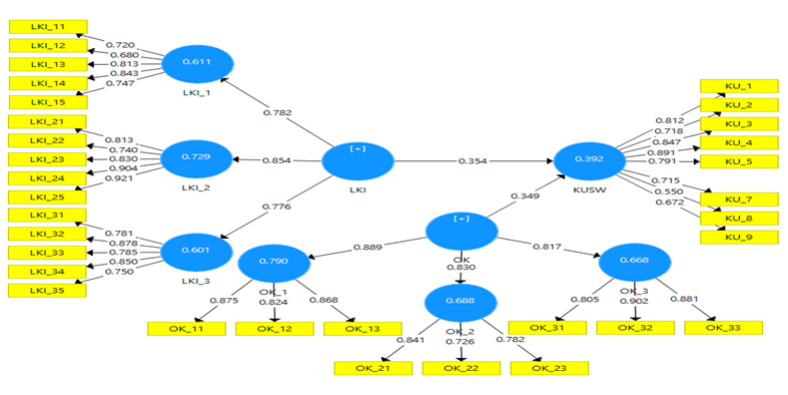

Figure 6: Confirmatory Factor Analysis

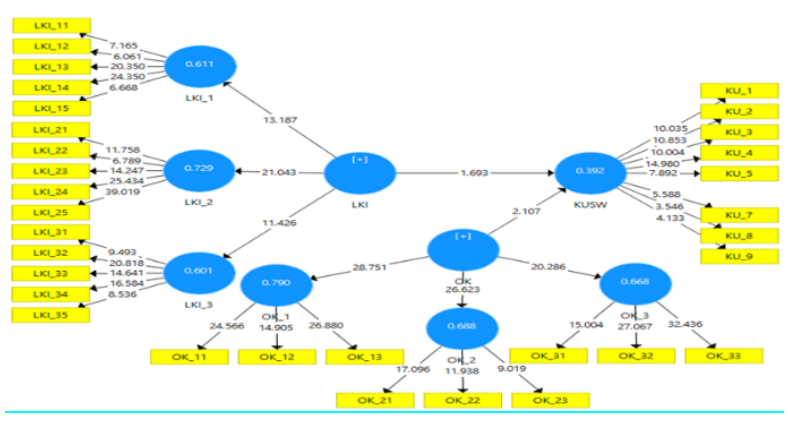

Figure 7: The T-Statistic Value Path Diagram 
Furthermore, for factor analysis (Second Order CFA), the validity of the indicator measurement model of the three dimensions of the Islamic financial literacy variable reflects a strong relationship, which is reflected in the loading factor values ranging from $>0.6->0.9$. By paying attention to the t-statistic value which is far above 1.96 and the P-value $<0.025$, it can be estimated that all indicators of these variables are valid to measure the latent variables (dimensions) respectively. The same condition is found in the entrepreneurial orientation variable, the indicators of the three dimensions also reflect a strong relationship, which is reflected in the loading factor values which are all> 0.70 , so it can be estimated that all indicators of these variables are valid to measure the latent variables (dimensions) of each.

Furthermore, the results of the structural model evaluation describe the relationship between the firstorder latent variable of Islamic financial literacy with the second-order latent dimensions of knowledge, attitudes, and behavior. The results of measuring the path coefficient value of each dimension to the construct of the reflective variable indicate that the loading factor value of each dimension of knowledge (LKI_1), attitude (LKI_2), and behavior (LKI_3) are all> 0.70 and tstatistic> 1.96 with P-Value 0,000 . The dimension of the LKI_2 variable, namely the attitude of Islamic finance, shows the highest value which can be interpreted as more dominant in building Islamic financial literacy variables. In the dimension of the Entrepreneurial Orientation variable, the loading factor value of each dimension of innovation, (OK_1), proactive, (OK_2), and Risk-taking (OK_3) all> 0.80 and t-statistic $>1.96$ with a P-value of 0.000 . OK_ 1 , namely the innovation dimension, shows the highest value which can be interpreted as more dominant in building entrepreneurial orientation variables. Thus, all dimensions of Islamic financial literacy and entrepreneurial orientation in measuring the estimated latent variables are valid.

Furthermore, for factor analysis (First-Order CFA) the validity of the measurement model for the business performance variable indicator, where the latent construct is reflected directly through the eight indicators has a moderate to a strong relationship, which is reflected in the loading factor value> $0.5->0.8$. By considering the t-statistic value which is far above 1.96 and the $\mathrm{P}$ value $<0.025$, it can be estimated that all indicators of this variable are valid to be used to measure the latent variables of business performance.

Evaluation of the structural model (inner model) for endogenous variables of business performance is carried out using the coefficient of determination ( $\mathrm{r}$ square / r2) indicator for the endogenous construct which aims to see how well the structural model (inner model) is formed. The test results show the values of $\mathrm{r} 2$ and $\mathrm{r} 2$ adjusted for business performance are 0.392 and 0.369 , which indicates that the exogenous latent variables of Islamic financial literacy and entrepreneurial orientation are only able to represent the endogenous latent variables of business performance by $36.9 \%$. It can also be interpreted that the diversity or measure of business performance of Muslim women entrepreneurs is more influenced by other variables.

\subsection{Effect of Islamic Financial Literacy on Business Performance}

The results of statistical testing as shown in Figure 7, produce a path coefficient of 0.354 indicating that there is an effect of Islamic financial literacy on business performance. with this path coefficient value is significant at the t-statistic 1.693 (>t-table 1.65) and Pvalue 0.046 (<significance level 0.05 ), which means that Islamic financial literacy significantly affects business performance. The positive effect of Islamic financial literacy on business performance statistically illustrates that an increase in a respondent's Islamic financial literacy unit will increase the value of financial decisions by 0.354 so that it can also be interpreted that the more literate a person is in Islamic finance, the more it will improve his business performance.

This result is in line with the descriptive findings related to the objective question of objective Islamic finance knowledge which has three indicators, the first indicator is related to the test regarding the concept of the time value of money, the majority of respondents answered correctly (80\%). For the second indicator related to two questions with the mudhorobah profitsharing scheme, respondents who answered correctly were $60 \%$ and $56 \%$, the rest answered wrong and did not know. The third indicator is related to questions related to financing products with a Murabaha buying and selling pattern, it is known that only $44 \%$ can answer correctly, the majority (55\%) answer they do not know and the rest answer wrong.

The results of this study are in line with the results of previous research by Fatoki (2014) and Wise Adomako et al, (2016) that if business actors have good financial literacy then implementing decisions related to their business will show more precise results. Likewise, Forbes Insights, 2011) states that financial literacy and inclusion can increase company growth.

\subsection{The Influence of Entrepreneurial Orientation on Business Performance}

The second hypothesis testing is intended to test the entrepreneurial orientation of business performance. The results of statistical testing as in Figure 7, produce a path coefficient of 0.349 , and with this path coefficient value is significant at the $\mathrm{t}$-statistic of 1.693 ( $>$ t-table 1.65) and a P-value of 0.046 (<significance level of 0.05) which indicates that there is a significant influence of entrepreneurial orientation on business performance. 
This can be interpreted that the higher the entrepreneurial orientation of women entrepreneurs, the better their business performance. This is in line with the statement of Keh et al (2007) that entrepreneurial orientation plays an important role in improving business performance.

The test results show that the innovation dimension has the greatest influence on business performance. It can be interpreted that an increase in business performance will occur when business actors continuously improve innovative behavior in running their business. Terziovski (2010) in the results of the study stated that the key driver of performance is the innovation factor, especially in the manufacturing business. However, proactive behavior also cannot be abandoned, namely by always trying to find business opportunities with the existing situation. Entrepreneurs cannot close their eyes and are quite happy with the businesses they currently have, but must always seek broader market information with information technology and dare to take risks as capital to increase business.

\section{CONCLUSIONS}

Based on the results of the research conducted, it can be concluded that overall this research has achieved its objectives and found that:

a. In terms of age, type of business, length of business, Muslim women entrepreneurs have an average level of Islamic financial literacy which is not much different, except that the level of education of $\mathrm{S} 1$ is relatively higher in the level of financial literacy.

b. The level of knowledge of Muslim women entrepreneurs towards sharia products and contracts is relatively good, this is evidenced by the answers to objective questions as basic knowledge of financial literacy can be answered correctly, except for questions about murabahah contract financing simulations, more people who answered did not know. Likewise, from the subjective statement as a whole, the score compared to the maximum score in the variable level of Islamic financial literacy is 3.85 $(82 \%)$ which is in the Literate range.

c. Islamic financial literacy through the dimensions of knowledge, attitudes, and behavior significantly affects business performance, likewise, entrepreneurial orientation through the dimensions of innovation, proactive, and risk-taking also has a significant effect on business performance. Thus, to improve the efforts of Muslim women entrepreneurs, they must continue to strive to improve knowledge, attitudes, and behavior of Islamic finance and improve entrepreneurial orientation.

\section{SUGGESTION}

a. Referring to the research findings which reveal that Islamic financial literacy has a significant influence on business performance, therefore it is considered important to increase Islamic financial literacy in society, especially Muslim women entrepreneurs with the following strategies:

1. Socialization of Islamic finance through training programs using contract simulations and products used in Islamic financial institutions.

2. Continuously distribute leaflets related to contracts and Islamic financial products with attractive and easy-to-understand packaging through printed or online media.

3. At the macro level, there is a need for government intervention to immediately include Islamic finance material in the school curriculum so that students from an early age can gain knowledge of Islamic finance to develop strategies to increase Islamic financial literacy.

Synergy is needed for all parties in an integrated, comprehensive, and sustainable manner between the government as a determinant of policies/regulations and infrastructure and products, the banking community (leaders of Islamic banks), Islamic finance practitioners, academics, Ulama / Da'i, and the community to work hand in hand to help improve Islamic financial literacy.

1. Product innovation that follows market developments and customer desires should always be done for women entrepreneurs, to be more proactive in looking for new product development opportunities with and of course a risk-taking attitude which also needs to be considered in carrying out activities. Efforts are needed to improve product quality, and more precise marketing techniques by utilizing information technology that is currently developing rapidly.

\section{AUTHORS' CONTRIBUTIONS}

The title "AUTHORS' CONTRIBUTIONS" should be in all caps.

\section{ACKNOWLEDGMENTS}

1) Directorate of Research and Community Service Directorate General of Research and Development Strengthening, Kemenristekdikti for funding support for this gender scheme research;

2) The Rector of Jambi University has encouraged researchers to develop themselves in implementing the Tri Dharma of Higher Education. 
3) Dean of the Faculty of Business and Management has motivated lecturers to improve their performance in research.

4) Chairperson and Staff of Research and Community Service (P2M) Jambi University, who provided technical and administrative support in this research.

5) Mothers of Muslim women entrepreneurs in Jambi City, who have been designed to be respondents in this study.

6) As well as all Parties that cannot be mentioned one by one, who have provided encouragement and help in this research.

\section{REFERENCES}

[1] Casson, M., Yeung, B., Basu, A., and Wadeson, N. (ed). (2006).The Oxford Handbook of Entrepreneurship.New York: Oxford University Press Inc.

[2] International Labour Office, I. (2018). Constraints and good practice in women's entrepreneurship in MENA (Issue 10).

[3] Kumbhar, V. 2013. Some critical issues of women entrepreneurship in Rural India. European Academic Research 1(1):5.

[4] Bhabha, J. I., Khan, S., Qureshi, Q. A., Naeem, A., \& Khan, I. (2014). Impact of Financial Literacy on Saving-Investment Behavior of Working Women in the Developing Countries. Research Journal of Finance and Accounting, 5(13), 118-123

[5] Widdowson, D. \& Hailwood, K., 2007. Financial Literacy And Its Role In Promoting A Sound Financial System. Reserve Bank of New Zealand: Bulletin, Volume 70(2), pp.37 - 47

[6] Usama, K. M., Fauziah, W., \& Yusoff, W. (2018). The Relationship Between Entrepreneurs' Financial Literacy and Business Performance Among Entrepreneurs of Bauchi State Nigeria. International Journal of Entrepreneurship and Business Innovation, 1(1), 15-26. www.abjournals.org

[7] Van Rooij, M., Lusardi, A., \& Alessie, R. (2011). Financial literacy and stock market participation. Journal of Financial Economics, 101, 449-472

[8] Atkinson, A., \& Messy, F. (2012). "Measuring Financial Literacy: Results of the OECD / International Network on Financial Education (INFE) Pilot Study. "

[9] Nidar, S.R. \& Bestari, S., 2012. Personal Financial Literacy Among University Students (Case Study at Padjadjaran University Students, Bandung,
Indonesia). World Journal of Social Sciences, 2(4), pp.162-171.

[10] Guiso, L. \& Jappelli, T., 2009. Financial Literacy and Portfolio Diversification., (January).

[11] Frank, H., Kessler, A., \& Fink, M. (2010). Entrepreneurial Orientation and Business PerformancE - A Replication Study*. SBR 62(April), 175-198.

[12] Su, Z., Xie, E., \& Li, Y. (2011). Entrepreneurial Orientation and Firm Performance in New Ventures and Established Firms. Journal of Small Business Management, $\quad 49(4), \quad 558-577$. https://doi.org/10.1111/j.1540-627X.2011.00336.X

13] Okangi, F. P. (2019). The impacts of entrepreneurial orientation on the profitability growth of construction firms in Tanzania. Journal of Global Entrepreneurship Research, 9(1), 1-23. https://doi.org/10.1186/s40497-018-0143-1

[14]Mason, M. C., Floreani, J., Miani, S., Beltrame, F., \& Cappelletto, R. (2015). Understanding the Impact of Entrepreneurial Orientation on Smes' Performance. the Role of the Financing Structure. Procedia Economics and Finance, 23(October 2014), 1649-1661. https://doi.org/10.1016/s22125671(15)00470-0

[15] Lawal, F. (2018). Risk-Taking: Implications for Improving the Performance of Small and Medium Enterprises (Smes) in Nigeria. ResearchGate, 17(January), 1-13.

[16] Omar, N. A., Md Aris, H., \& Nazri, M. A. (2016). The effect of entrepreneurial orientation, innovation capability and knowledge creation on firm performance: A perspective on small scale entrepreneurs. Jurnal Pengurusan, 48(2016), 187200. https://doi.org/10.17576/pengurusan-2016-4815

[17] Eniola, A. A., Entebang, H., \& Sakariyau, O. B. (2015). Small and medium scale business performance in Nigeria: Challenges faced from an intellectual capital perspective. International Journal of Research Studies in Management, 4(1), 57-71. http://dx.doi.org/10.5861/ijrsm.2015.964

[18] Andoh, F. K., Nunoo, J., \& Darfor, N. K. (2015). Sustaining Small and Medium Enterprises through Financial Service Utilization: Does Financial Literacy Matter? Journal of Business and Enterprise Development, 5(1), 74-94.

[19] Bruhn, M., \& Zia, B. (2013). Stimulating managerial capital in emerging markets: The impact of business training for young entrepreneurs. Journal of Development Effectiveness, 5(2), 232 
266.

https://doi.org/10.1080/19439342.2013.780090

[20] Bowen, M., Morara, M., \& Mureithi, M. (2009). Management of Business Challenges Among Small and Micro Enterprises in Nairobi-Kenya. KCA Journal of Business Management, 2(1), 16-31. https://doi.org/10.4314/kjbm.v2i1.44408

[21] Lusimbo, E. N., \& Muturi, W. (2016). Financial Literacy and the Growth of Small Enterprises in Kenya: a Case of Kakamega Central Sub-County, Kenya. International Journal of Economics, Commerce and Management, iv(6), 828-845. http://ijecm.co.uk/

[22] Hikmah. (2020). The Effect of Bookkeeping Literacy, Budgeting Literacy, And Financial Inclusion of SME Financial Performance In Semarang. International Journal of Economics and Management Studies, 7(6), 23-27. https://doi.org/10.14445/23939125/ijems-v7i6p103

[23] Chepngetich, P. (2016). Effect of Financial Literacy and Performance SMEs. Evidence from Kenya. American Based Research Journal, 5(2016-11), 26-35. http://www.abrj.org

[24] Fatoki, O. 2014. The financial literacy of microentrepreneurs in South Africa. Journal of Social Science. 40(2). 151 - 158.

[25] Setiawati, R., Nidar, S. R., Anwar, M., \& Masyita, D. (2018). Islamic Financial Literacy: Construct Process and Validity. Academy of Strategic Management Journal, 17(4),1-12.

[26] Razak, L. A. (2015). Exploratory Research into Islamic Financial Literacy in Brunei Darussalam, (Oktober).

http://doi.org/10.13140/RG.2.1.4815.1765

[27] Salehudin, I., 2010. Halal Literacy: A Concept Exploration and Measurement Validation. Asian Marketing Journal, II(1), p.12.

[28] Antara, P.M., Musa, R. \& Hassan, F., 2016. Bridging Islamic Financial Literacy and Halal Literacy: The Way Forward in Halal Ecosystem. Procedia Economics and Finance, 37(16), pp.196202. Available at: http://dx.doi.org/10.1016/S22125671(16)30113-7.

[29] Lumpkin, G. T., \& Dess, G. G. (2015). Taxonomy of the determinants of entrepreneurial activity. Journal of Economics and Economic Education Research, 16(3), 119-144.

[30] Lee, S. M., \& Peterson, S. J. (2000). Culture, entrepreneurial orientation, and global competitiveness. Journal of World Business, 35(4),
401-416. $\underline{9516(00) 00045-6}$

https://doi.org/10.1016/S1090-

[31] Frishammar, J., Hörte, S. A. (2007). The Role of Market Orientation and Entrepreneurial Orientation for New Product Development Performance in Manufacturing Firms. Technology Analysis \& Strategic Management, Vol. 19, No. 6, 765-788. https://www.tandfonline.com/loi/ctas20

[32] Benneth Uchenna, E., Moruff Sanjo, O., \& Joseph, F. (2019). Entrepreneurial Orientation and Micro, Small and Medium Enterprises (MSMES) Performance in Abia State, Nigeria. Covenant Journal of Entrepreneurship (CJoE), 3(1).

[33] Arshad, A. S., Rasli, A., Arshad, A. A., \& Zain, Z. M. (2014). The Impact of Entrepreneurial Orientation on Business Performance: A Study of Technology-based SMEs in Malaysia. Procedia Social and Behavioral Sciences, 130(1996), 46-53. https://doi.org/10.1016/j.sbspro.2014.04.006

[34] Radipere, S. (2014). The effects of entrepreneurial orientation on business performance. Mediterranean Journal of Social Sciences, 5(16), 141-152.

https://doi.org/10.5901/mjss.2014.v5n16p141 